\title{
HUBUNGAN ANTARA KEMAMPUAN MUHADATSAH DENGAN NILAI TOAFL DI STAIN CURUP
}

\author{
Noza Aflisia \\ Sekolah Tinggi Agama Islam Negeri Curup \\ E-mail: naflisia@yahoo.co.id
}

\begin{abstract}
To measure the level of Arabic skill of students in State Collage For Islamic Studies Curup addition to the value obtained directly from the lecturers Arabic, the skill of Arabic can also be known through the TOAFL. TOAFL results obtained by students vary and have interesting phenomena to be examined by the author. There are among students who have good muhadatsah skills but get a low TOAFL score, some also have less muhadatsah skill, but get high TOAFL score. With this research is expected to find whether there is a relationship between the muhadatsah skill of State Collage For Islamic Studies Curup students with TOAFL score. Then how significant the corelation both of them. The approach of this research is quantitative descriptive, with correlation method. The primary data source is the student's muhadatsah score and the TOAFL score. Data collection techniques used in this study are interviews, documentation and observation. To know the relationship between variables $x$ and $y$ used correlation coefficient analysis using Product Moment formula. The result of this research is there is positive relation with medium category between muhadatsah skill with score of TOAFL student of State Collage For Islamic Studies Curup. It also found other factors that affect the score of TOAFL, namely good psychological conditions, healthy physical, precise strategy, experience and luck.
\end{abstract}

Keyword: Muhadatsah, TOAFL score, State Collage For Islamic Studies Curup

\begin{abstract}
Abstrak
Untuk mengukur tingkat kemampuan bahasa Arab mahasiswa di STAIN Curup selain nilai yang diperoleh langsung dari dosen pengampu mata kuliah bahasa Arab, kemampuan bahasa Arab juga dapat diketahui melalui tes TOAFL. Hasil TOAFL yang diperoleh mahasiswa berbeda-beda dan memiliki fenomena menarik untuk diteliti oleh penulis. Ada diantara mahasiswa yang memiliki kemampuan muhadatsah yang baik namun mendapatkan nilai TOAFL rendah, ada juga yang memiliki kemampuan muhadatsah yang kurang, namun mendapat nilai tinggi. Dengan adanya penelitian ini diharapkan dapat menemukan apakah ada hubungan antara kemampuan muhadatsah mahasiswa STAIN Curup dengan nilai TOAFL. Kemudian seberapa besar hubungan antara keduanya. Pendekatan penelitian ini adalah deskriptif kuantitatif, dengan metode korelasi. Sumber data primer adalah nilai muhadatsah mahasiswa dan nilai TOAFL. Teknik pengumpulan data yang digunakan dalam penelitian ini adalah wawancara, dokumentasi dan observasi. Untuk mengetahui hubungan antara variabel $\mathrm{x}$ dan y digunakan analisis koefisien korelasi dengan menggunakan rumus Product Moment. Adapun hasil dari penelitian ini adalah terdapat hubungan positif dengan kategori sedang antara kemampuan muhadatsah dengan nilai TOAFL mahasiswa Prodi Pendidikan Bahasa Arab STAIN Curup. Selain itu juga ditemukan faktor-faktor lain yang mempengaruhi nilai TOAFL, yaitu kondisi psikologis yang baik, fisik yang sehat, strategi jitu, pengalaman dan keberuntungan.
\end{abstract}

Kata Kunci: Muhadatsah, Nilai TOAFL, STAIN Curup 


\section{A. Pendahuluan}

Bahasa merupakan senjata utama dalam berkomunikasi agar apa yang disampaikan oleh seseorang dapat dimengerti oleh lawan bicaranya. Oleh sebab itu, tidak heran jika banyak orang yang mempelajari berbagai macam bahasa. Tidak cukup hanya dengan bahasa Ibu, ataupun bisa berbahasa Indonesia yang baik dan benar. Apalagi sebagai warga Negara Indonesia yang mayoritas penduduknya beragama Islam, di sini bahasa Arab juga seyogyanya dikuasai oleh penganut agama Islam ini. Karena Al-Qur'an yang merupakan sumber ajaran umat Islam tertulis dalam bahasa Arab. Dalam dunia pendidikan selain bahasa Inggris, Bahasa Arab juga diperlukan oleh pembelajar. Sebagai bentuk realisasi hal ini, maka memiliki kemampuan berbahasa Arab ditekankan kepada mereka, hingga pelajaran Bahasa Arab sekarang telah ada dalam kurikulum pendidikan, mulai dari pendidikan dasar hingga pendidikan tinggi, seperti di STAIN Curup yang merupakan salah satu perguruan tinggi yang ada di Indonesia, tepatnya di wilayah Rejang Lebong.

Di STAIN Curup mata kuliah Bahasa Arab dimasukkan untuk semua program studi. Untuk mengukur tingkat kemampuan bahasa Arab mahasiswa, selain nilai yang diperoleh langsung dari dosen pengampu mata kuliah bahasa Arab, kemampuan bahasa Arab juga dapat diketahui melalui tes TOAFL.

TOAFL adalah singkatan dari "Test of Arabic as a Foreign Language". TOAFL dilaksanakan sebagai standarisasi penilaian bahasa Arab. Dengan adanya standarisasi tersebut, diharapkan mampu menekan peserta didik sehingga memiliki keterampilan bahasa Arab yang matang. Standarisasi penilaian bahasa Arab ini telah banyak dilaksanakan di Perguruan-perguruan Tinggi di Indonesia, baik negeri mapun swasta. STAIN Curup telah melaksanakan tes ini terhitung sejak tahun 2015 dibawah pengawasan Unit Pengembangan Bahasa (UPB). Tes ini bukan saja diharuskan bagi mahasiswa prodi Pendidikan Bahasa Arab tapi diberlakukan sama untuk seluruh mahasiswa sebagai salah satu syarat bagi mahasiswa yang ingin mengikuti wisuda. Tes TOAFL dilaksanalkan berkali-kali dalam setahun. Hasil TOAFL yang diperoleh mahasiswa pun berbeda-beda dan memiliki fenomena menarik untuk diteliti oleh penulis. Ada diantara mahasiswa yang memiliki kemampuan muhadatsah yang baik namun mendapatkan nilai TOAFL rendah, ada juga yang memiliki kemampuan muhadatsah yang kurang, namun mendapat nilai tinggi.

Dengan adanya penelitian ini diharapkan dapat menemukan apakah ada hubungan antara muhadatsah mahasiswa STAIN Curup dengan nilai TOAFL. Kemudian seberapa besar hubungan antara keduanya.

\section{B. Metode Penelitian}

Pendekatan penelitian ini adalah deskriptif kuantitatif, dengan metode korelasi yaitu yang menerangkan seberapa besar pengaruh kemampuan muhadatsah terhadap nilai TOAFL. Populasi dan sampel penelitian adalah mahasiswa prodi Pendidikan Bahasa Arab semester VIII A pada tahun ajaran 2016-2017 yang berjumlah 19 orang.

Penelitian ini terdiri dari dua variabel yaitu variabel $\mathrm{x}$ (kemampuan muhadatsah) dan variabel y (nilai TOAFL). Sumber data dalam penelitian ini adalah subjek dari mana data dapat diperoleh. Data yang harus dikumpulkan berupa data primer dan data sekunder. Adapun yang dijadikan sumber data 
primer adalah nlai muhadatsah mahasiswa prodi Pendidikan Bahasa Arab semester VIII A yang didapatkan dari dosen yang mengajar muhadatsah dan nilai TOAFL yang didapatkan dari Unit Pengembangan Bahasa selaku penanggung jawab penyelenggara TOAFL di STAIN Curup. Sedangkan data sekunder diperoleh atau dikumpulkan oleh orang yang melakukan penelitian dari sumbersumber yang telah ada, diantaranya adalah data-data berupa dokumen atau arsiparsip.

Untuk memperoleh informasi dan data dari mahasiswa, penulis menggunakan metode snowballing yaitu untuk memperoleh informasi dan data mengenai faktor-faktor lain yang mempengaruhi nilai TOAFL rendah ataupun tinggi. Dalam hal ini peneliti melakukan wawancara terhadap satu orang mahasiswa kemudian penulis mewawancarai mahasiswa yang lain sebagai pembanding. Demikian seterusnya sampai peneliti menemukan titik jenuh yaitu mendapatkan satu kesimpulan jawaban yang sama.

Adapun teknik pengumpulan data yang digunakan dalam penelitian ini adalah:

Pertama, Wawancara adalah sekumpulan pertanyaan yang diajukan secara verbal kepada orang-orang yang dianggap dapat memberikan informasi atau penjelasan hal-hal yang dipandang perlu. ${ }^{1}$ Dalam hal ini wawancara dilakukan untuk mengetahui faktor-faktor yang mempengaruhi kemampuan muhadatsah dan nilai TOAFL.

Kedua, Dokumentasi yaitu suatu metode penelitian yang mencari data mengenai hal-hal atau variabel yang berupa catatan, transkrip, buku, surat kabar, majalah, prasasti, notulen rapat, legger, agenda, dan sebagainya. ${ }^{2}$ Dokumentasi ini digunakan untuk mendapatkan data tentang nilai-nilai muhadatsah dan TOAFL STAIN Curup.

Ketiga, Observasi adalah suatu proses yang kompleks, suatu proses yang tersusun dari berbagai proses biologis dan psikologis. Dua diantara yang terpenting adalah proses-proses pengamatan dan ingatan. ${ }^{3}$ Dalam penelitian ini, observasi dilakukan untuk memperoleh data tentang letak geografis, situasi dan kondisi Unit Pengembangan Bahasa (UPB) Sekolah Tinggi Agama Islam Negeri (STAIN) Curup.

Untuk mengetahui hubungan antara variabel $\mathrm{x}$ dan y digunakan analisis koefisien korelasi dengan menggunakan rumus Product Moment sebagai berikut:

Rumus :

$\mathrm{r}_{11 / 22}=\frac{\mathrm{N} \sum X Y-\left(\sum X\right)\left(\sum Y\right)}{\sqrt{\left[\mathrm{N} \sum X 2-(\Sigma X) 2\right]\left[\mathrm{N} \Sigma Y 2-\left(\sum Y\right) 2\right]}}$

\section{Tabel I}

\section{Interpretasi Koefisien Korelasi ${ }^{4}$}

\footnotetext{
${ }^{1}$ Rochiati Wiraatmadja, Metode Penelitian Tindakan Kelas, (Bandung : Remaja Rosdakarya, 2005), h. 117

${ }^{2}$ Suharismi Arikunto, Prosedur Penelitian, (Jakarta: PT. Rineka Cipta, 2010), h. 206

${ }^{3}$ Sugiyono. Metode Penelitian Pendidikan, Pendekatan Kuantitatif, Kualitatif, dan R\&D, Cetakan ke-17, (Bandung: Alfabeta, 2012), hal. 145

${ }^{4}$ Ibid.,
} 


\begin{tabular}{|c|c|}
\hline Interval Koefisien & Tingkat Hubungan \\
\hline $0,00-0,199$ & Sangat Rendah \\
\hline $0,20-0,399$ & Rendah \\
\hline $0,40-0,599$ & Sedang \\
\hline $0,60-0,799$ & Kuat \\
\hline $0,80-1,000$ & Sangat Kuat \\
\hline
\end{tabular}

\section{Hasil dan Pembahasan}

\section{A. Muhadatsah}

\section{Pengertian Muhadatsah}

Menurut bahasa muhadatsah adalah percakapan, dialog atau berbicara. Muhadatsah adalah kegiatan seseorang dalam menggunakan suara, intonasi, atau kalimat-kalimat untuk mengungkapkan pikiran seperti pendapat, keinginan dan perasaan. Menurut Muhammad Shalihuddin 'Ali Majawir bahwa muhadatsah bisa disebut sebagai ta'bir syafahi (ungkapan secara lisan) yakni bahwasanya muhadatsah itu adalah ucapan seseorang yang mengungkapkan ide, pikiran, pendapat dan lain sebagainya. Keterampilan berbicara atau muhadatsah adalah kemampuan mengungkapkan pendapat atau pikiran dan perasaan kepada seseorang atau kelompok secara lisan, baik secara berhadapan ataupun dengan jarak jauh. ${ }^{5}$

Percakapan merupakan pertukaran pikiran atau pendapat mengenai suatu topik tertentu antara dua atau lebih. Percakapan merupakan dasar keterampilan berbicara baik bagi anak-anak maupun orang tua. Pembelajaran Muhadatsah (berbicara) merupakan pembelajaran bahasa Arab yang pertama-tama diajarkan. Tujuannya adalah agar siswa mampu bercakap-cakap (berbicara) dalam pembicaraan sehari-hari dengan menggunakan bahasa Arab dan dalam membaca Al-Quran dalam sholat dan berdoa.

Dalam setiap bahasa terdapat unsur-unsur yang dapat dilihat secara terpisah-pisah, meskipun satu sama lain saling berhubungan dengan erat bahkan menyatu sehingga terbentuk sebuah fenomena yang bernama bahasa. Performansi dan kemampuan berbahasa juga bermacam-macam. Ada yang berbentuk lisan dan ada yang berbentuk tulisan. Ada yang bersifat reseptif (menyimak dan membaca) dan ada yang bersifat produktif (berbicara dan menulis). Dan telah dijelaskan pula bahwa pengajaran bahasa didalamnya terdapat unsur-unsur seperti tata bunyi, keterampilan berbahasa yang terdiri atas: membaca (al-Qira'ah), menulis (al-kitabah), berbicara (al-Kalam), dan menyimak (al-Istima') untuk melatih dan mengajarkan masing-masing unsur dan ketrampilan tersebut, telah dikembangkan berbagai cara atau teknik.

Keterampilan berbicara (maharah al-kalam) adalah kemampuan mengungkapkan bunyi-bunyi artikulasi atau kata-kata untuk mengekspresikan pikiran berupa ide, pendapat, keinginan, atau perasaan kepada mitra bicara. Dalam makna yang lebih luas, berbicara merupakan suatu system tanda-tanda

${ }^{5}$ Tim Penyusun Kamus Pusat Bahasa, Kamus Besar Bahasa Indonesia, Edisi ketiga, (Jakarta, Balai Pustaka, 2005), h. 17 
yang dapat didengar dan dilihat yang memanfaatkan sejumlah otot tubuh manusia untuk menyampaikan pikiran dalam rangka memenuhi kebutuhannya. ${ }^{6}$

Dengan demikian yang dimaksud pembelajaran muhadatsah adalah cara menyajikan bahasa dalam pelajaran bahasa Arab melalui percakapan, dan percakapan itu dapat terjadi antara pendidik (guru) dan terdidik (murid) atau antara murid dengan murid sambil memperkaya perbendaharaan kata-kata vocabulary yang semakin banyak.

\section{Tujuan Pembelajaran Muhadatsah}

Pada proses kegiatan pembelajaran, tujuan merupakan hal pokok yang tidak boleh diabaikan oleh setiap lembaga pendidikan. Karena dengan adanya tujuan dalam proses pembelajaran, menandakan bahwa proses pembelajaran tersebut mempunyai arah dan target yang jelas akan apa yang telah menjadi cita-cita yang hendak dicapai.

Untuk mencapai suatu tujan tentunya dibutuhkan adanya hubungan yang harmonis antara komponen-komponen yang terlibat didalam pembelajaran tersebut. Seperti tujuan, metode, media pembelajaran, siswa dan guru.

Begitu juga dengan pembelajaran muhadatsah, tujuan merupakan satu hal yang menjadi prioritas utama yang harus dicapai. Menurut Ahmad Izzan tujuan pengajaran keterampilan bahasa Arab (Muhadatsah) adalah: ${ }^{7}$

a. Melatih lidah anak didik agar terbiasa dan fasih bercakap-cakap (berbicara) dalam bahasa Arab.

b. Terampil berbucara dalam bahasa Arab mengenai kejadian apa saja di dalam masyarakat dan dunia internasional yang diketahui.

c. Mampu menerjemahkan percakapan orang lain lewat telepon, radio, tv, tape recorder dan lain-lain.

Menumbuhkan rasa cinta dan menyenangi bahasa Arab dan Al-Qur'an sehingga timbul kemauan untuk belajar dan mendalaminya

Sedangkan tujuan Muhadatsah menurut Ahmad Fuad Effendy adalah apabila dilihat secara umum tujuan latihan berbicara untuk tingkat pemula dan menengah ialah agar siswa dapat berkomunikasi lisan secara sederhana dalam berbahasa Arab. Sedangkan tujuan akhir latihan pengucapan adalah pengucapan ekspresi (ta'bir) yaitu yaitu mengemukakan ide/pikiran/pesan kepada orang lain.

\section{Metode dalam Pembelajaran Muhadatsah dan Langkah Penyajiannya}

Dalam pengajaran keterampilan berbicara bahasa Arab ada beberapa metode yang dapat digunakan, diantaranya:

a. Metode Langsung

Adapun langkah-langkah penyajian metode langsung ini secara umum sebagai berikut : ${ }^{8}$

1) Guru memulai penyajian materi secara lisan, mengucapkan satu kata dengan menunjukkan bendanya atau gambar benda itu. Pelajar

${ }^{6}$ Acep Hermawan, Metodologi Pembelajaran Bahasa Arab, (Bandung: PT Remaja Rosdakarya Offset, 2009), 135.

${ }^{7}$ Ahmad Izzan, Metodologi Pembelajaran Bahasa Arab, (Bandung: Humaniora, 2007), h.

${ }^{8}$ Ahmad Fuad Effendy, Metodologi Pengajaran Bahasa Arab, (Malang: Misykat, 2012), h. 49-50 
menirukan berkali- kali samapai benar pelafalannya dan faham maknanya.

2) Latihan berikutnya brupa tanya jawab dengan kata tanya " $m a$, hal, aina, dan sebagainya sesuai dengan tingkat kesulitan pelajaran, berkaitan dengan kata kata yang disajikan.

3) Setelah guru yakin bahwa menguasai materi yang disajikan, baik dalam pelafalan maupun pemahaman makna, siswa dimainta membuka buku teks. Guru memberikan contoh bacaan yang benar kemudian siswa diminta membaca secara bergantian.

4) Kegiatan berikutnya adalah menjawab secara lisan pertanyaan atau latihan yang ada dalam buku, dilanjutkan dengan mengajarkanya secara tertulis.

5) Bacaan umum yang sesuai dengan tingkatan siswa diberikan sebagai tambahan, misalnya berupa cerita humor, cerita yang mengandung hikmah, dan bacaan yang mengandung ungkapan ungkapan indah. Karena pendek dan menarik, siswa menghafalkanya diluar kepala.

b. Metode Audiolingual

Langkah-langkah penyajian metode audio lingual adalah sebagai berikut: ${ }^{9}$

1) Penyajian dialog atau bacaan pendek, dengan cara guru membacanya berulang kali, dan pelajar menyimak tana meihat teks.

2) Peniruan dan penghafaan dialog atau bacaan pendek, dengan teknik menirukan bacaan guru kalimat per kalimat secara klasikal, sambil menghafalkan kalimat-kalimat tersebut. Teknik ini disebut mimicrymemorization (mim-mem) technique.

3) Penyajian pola-pola kalimat yang terdapat dalam dialog atau bacaan pendek, terutama yang dianggap sukar, karena terdapat struktur dalam bahasa ibu pelajar. Ini diakukan dengan teknik dri yang umumnya bersifat mekanis.

4) Dramatisasi dialog atau bacaan pendek yang sudah dilatihkan. Pelajar memeragakan atau mendramatisasikan dialog yang sudah dihafalkan didepan kelas secara bergantian.

5) Latihan membuat kalimat-kalimat lain yang sesuai dengan pola-pola kalimat yang sudah dipelajari.

c. Metode Komunikatif

Salah satu prosedur proses belajar mengajar dalam PK dilukiskan oleh Finochiaro dan Brumfit sebagai berikut: ${ }^{10}$

1) Dialog pendek disajikan dengan didahului penjelasan tentang fungsifungsi ungkapan dalam dialog itu dan situasi di mana dialog itu mungkin terjadi.

2) Latihan mengucapkan kalimat-kalimat pokok secara perorangan, kelompok atau klasikal.

3) Pertanyaan diajukan tentang isi dan situasi dalam dialog itu, dilanjutkan pertanyaan serupa tetapi langsung mengenai situasi masing-masing pelajar. Di sini kegiatan komunikatif yang sebenarnya telah dimulai.

4) Siswa membahas ungkapan-ungkapan komunikatif dalam dialog

\footnotetext{
${ }^{9}$ Ibid., hal. 61-62

${ }^{10}$ Ibid., hal. 91-92
} 
5) Siswa diharapkan menarik sendiri kesimpulan tentang aturan tata bahasa yang termuat dalam dialog. Guru memfasilitasi dan meluruskan apabila terjadi kesalahan dan penyimpulan

6) Pelajar melakukan kegiatan menafsirkan dan menyatakan suatu maksud dari latihan komunikasi yang lebih bebas dan tidak sepenuhnya berstruktur.

7) Pengajar melakukan evaluasi dengan mengambil sampel dari penampilan pelajar dalam kegiatan komunikasi bebas.

\section{Materi Pengajaran Muhadatsah}

Bahan Pelajaran atau materi adalah substansi yang akan disampaikan dalam proses belajar mengajar. ${ }^{11}$ Dalam kaitannya dengan pemilihan materi, guru tidak mungkin memilih atas kemauannya sendiri, tetapi didasari oleh pedoman umum yang telah terumuskan oleh para ahli.

Bahan pelajaran harus dirumuskan dan disusun sedemikian rupa agar dapat menunjang tercapainya tujuan pengajaran. Dengan demikian harus terdapat hubungan yang harmonis dan sistematis antara tujuan yang hendak dicapai dengan materi pelajaran yang disediakan.

Adapun materi Muhadatsah pada umumnya berupa pola-pola kalimat yang terdiri dari beberapa kata yang tersusun dan mengandung faedah atau pengertian. Materi Muhadatsah tidak bisa disajikan seluruhnya kepada siswa, melainkan diajarkan secara bertahap dan perlu diadakan seleksi terhadap materi yang diajarkan, seleksi didasarkan bahwa materi tersebut harus:

1) Dipandang penting

2) Sesuai dengan kemampuan siswa

3) Yang sering digunakan dalam kehidupan sehari-hari

4) Frekuensi pemakaiannya luas.

\section{Media Pengajaran Muhadatsah}

Media pembelajaran yang dapat dimanfaatkan untuk pembelajaran keterampilan berbicara bahasa Arab adalah antara lain papan tulis, papan display, papan magnetis, dan kesemuanya itu bisa dimanfaatkan untuk mendisplay kartu mufradat dan kartu-kartu lain. Adapun media selain papan tersebut yang dapat dimanfaatkan seperti: ${ }^{12}$

a) Jam dinding (Qorshus Sa'ah)

Jam dinding adalah media yang paling sukses dalam melatih siswa dalam keterampilan berbicara. Media ini mudah dibuat dan didapatkan oleh seorang guru, biasanya terdiri dari angka 1-12, jarum panjang, jarum sedang, dan jarum pendek.namun sebelum menggunakan media jam dinding ini. Harus dipastikan bahwa siswa sudah mengenal hitungan satu sampai enam puluh. Langkah berikutnya adalah guru memutar jarum jam sebagaimana biasanya, setelah dipastikan jarum jam menunjukkan angka tertentu, maka guru melontarkan beberapa pertanyaan.

b) Film

Adapun langkah-langkah yang harus dilakukan oleh guru ketika menggunakan film sebagai media pembelajaran keterampilan berbicara

\footnotetext{
${ }^{11}$ Syaiful Bahri Djamarah dan Aswan Zain, Strategi Belajar Mengajar, (Jakarta: Rineka Cipta, 2006) h. 43

${ }_{12}$ Abdul Wahab Rosyidi, Media Pembelajaran Bahasa Arab, (Malang: UIN Malang Press, 2009), h. 67-70
} 
adalah memutarkan film terlebih dahulu pada siswa kemudian menanyakan secara lisan, apa judul film, siapa pelakunya, bagaimana akhir ceritanya. Atau dengan langkah lain siswa diminta untuk mengungkapkan ungkapanungkapan yang menarik menurutnya, atau diminta untuk bercerita secara singkat.

c) Mengungkapkan tema secara lisan

Mengungkapkan tema secara lisan yang dimaksud disini adalah mengungkapkan tema-tema tertentu yang dibantu dengan beberapa gambar, baik berupa cerita, percakapan, atau deskripsi. Biasanya di bawah gambar ada beberapa pertanyaan yang dapat membantu siswa untuk mengungkapkan tema-tema tersebut.

d) Karya wisata (Ar-Rihlah)

Karya wisata bisa dijadikan sebagai salah satu media untuk melatih keterampilan berbicara. Karena dengan belajar keluar dari kelas siswa akan mendapatkan sesuatu yang banyak yang ia lihat, setelah itu siswa diminta untuk menceritakan apa yang telah dilihatnya secara lisan. Tentunya penggunaan media ini harus mempertimbangkan seperti: tempay yang indah, dana, jauh, dan dekat.

Adapun media sederhana yang dapat digunakan dalam sebagai media pembelajaran keterampilan berbicara bahasa Arab adalah sebagai berikut: ${ }^{13}$

(1) Kartu

Kartu pada dasarnya adalah kertas tebal berbentuk persegi panjang untuk berbagai keperluan. ${ }^{14}$ Berikut ini adalah beberapa kartu yang dapat digunakan dalam pembelajaran keterampilan berbicara bahasa Arab, yaitu sebagai berikut:

(2) Kartu Kilat

Kartu kilat disebut juga Flashcard atau Bithaqah Wamdhiyah. Kartu kilat adalah kartu yang digunakan untuk mengenalkan kosa kata beserta maknanya dengan cara memperhatikannya secara cepat (beberapa detik) sambil melafalkan kata yang dimaksud dan siswa diminta menirukan. Kartu kilat digunakan secara klasikal. Karena itu kartu kilat dibuat dengan ukuran yang memadai yang memungkinkan siswa yang duduk si paling belakang pun dapat melihat dengan jelas gambar atau kata yang terdapat pada kartu kilat.

(3) Kartu Peran

Kartu peran merupakan kartu yang berisi deskripsi singkat tentang situasi yang harus dimainkan oleh seseorang. Kartu peran untuk suatu konteks pemeranan terdiri atas beberapa kartu sesuai dengan jumlah pemeran yang dirancang. Siswa yang memperoleh suatu kartu peran diminta membaca dan memahami peran yang akan dimainkan yang tertulis pada kartu itu. Dalam hal ini, pemeran yang satu tidak tahu apa yang akan dikatakan dan dilakukan oleh pemeran lainnya. Karena itu, setiap pemeran dituntut untuk berpikir dan berinteraksi secara cepat dan spontan.

\footnotetext{
13 Imam Asrori dan Moh. Ahsanuddin,Media Pembelajaran Bahasa Arab Dari Kartu Sederhana Sampai Web Penjelajah Dunia, (Malang: CV Bintang Sejahtera, 2016), hal. 33

${ }^{14}$ N.A. Ridwan, Kartu Kata dan Kartu Gambar sebagai media Pembelajaran Bahasa Arab di Madrasah Ibtidaiyah. Makalah disampaikan dalam Pelatihan Pembuatan dan Penggunaan Gambar dan Kartu Kata untuk Pembelajaran Bahasa Arab di Madrasah Ibtidaiyah, pada tanggal, 24-25 Juni 2006, (Malang: Jurusan Sastra Universitas Negeri Malang)
} 
(4) Peta

Peta secara umum tersedia di setiap sekolah/madrasah. Karena itu ketersediaannya perlu diperhatikan oleh pengajar bahasa Arab. Jika pengajar bahasa Arab dapat menggunakan peta secara kreatif dalam pembelajaran bahasa Arab, maka pembelajaran Bahasa Arab tidak akan kosong dari media. Contoh pengajaran keterampilan berbicara bahasa Arab dengan menggunakan media peta adalah sebagai berikut:

(a) Bertanya dengan ما هذ/ما هذا

Dalam hal ini pengajar bisa lakukan dengan menunjuk pada salah satu pulau pada peta lalu mengemukakan pertanyaan: هذا هذه dan segera dijawab sendiri dengan هذه جاوا. pengajar beralih menunjuk pulau lain dengan cara yang sama. Setelah bertanya-jawab sendiri guru meminta siswa menirukan Tanya jawab yang dituturkan. Untuk selanjutnya pengajar mengemukakan pertanyaan kepada siswa sambil menunjuk pada salah satu pulau lalu meminta siswa untuk menjawab.

(b) Bertanya dengan أين سورابايا

Latihan ini dimaksudkan untuk (a) membelajarkan kalimat Tanya dan kalimat pernyataan sederhana, (b) membelajarkan kata tugas "ayna" dan "fi", serta (c) memberikan informasi geografis. Dengan langkah-langkah yaitu pengajar menunjuk pada letak kota Surabaya sambil mengucapkan أين سورابايا lalu ia menjawab sendiri سورابايا في جاوا الثرقية, lalu pengajar meminta siswa mengulangi pertanyaan dan jawaban.

(c) Truktur Zharaf dan Bentuk Negasi

Latihan ini dimaksudkan untuk (a) membelajarkan struktur zharaf dan (b) kalimat negasi dengan melatihkan struktur zharaf dan bentuk negasi tersebut dapat ditempuh langkah-langkah yang digunakan pada pembelajaran terdahulu. Pertama, diawali dengan pemodelan dari guru. Kedua, peniruan oleh siswa secara kelasikal, berkelompok, atau perorangan. Ketiga, praktik oleh siswa secara berpasangan atau dalam kelompok. Dalam setiap latihan, siswa juga dapat dilibatkan sebagai intruktur yang memandu siswa lain secara bergantian

(d) Bahan Otentik

Bahan/kartu otentik dalam pembelajaran bahasa Arab pada dasarnya harus berbahasa target. Meskipun demikian, jika tidak dapat diperoleh Bahan Otentik berbahasa target, dapat dibuat bahan otentik tiruan. Diantara contoh bahan otentik adalah kartu nama toko emas, kartu maktab/majmu'ah haji di madinah, kartu nama, dan kartu identitas.

Kartu identitas dapat digunakan untuk melatih percakapan perdasarkan isi atau pesan yang terdapat dalam kartu tersebut. Begitu juga dengan brosur-brosur promosi minimarket atau supermarket dapat digunakan untuk melatih percakapan bahasa Arab.

\section{Evaluasi Pengajaran Keterampilan Berbicara Bahasa Arab}


Untuk melakukan evaluasi keterampilan berbicara bahasa Arab dapat dilakukan melalui beberapa tes sebagai berikut: ${ }^{15}$

a. Tes Pelafalan

Tes pelafalan seperti menirukan pelafalan, melafalkan tekanan dan intonasi, membaca nyaring teks yang sudah dihafal, menyempurnakan kalimat, menjawab pertanyaan sesuai sketsa, dan membaca bersuara.

b. Tes Praktek Struktur (qawaid) secara verbal

Tes ini berupa mengubah kata atau kalimat, menghubungkan kalimat, saling bertanya jawab, mengubah kalimat pernyataan menjadi pertanyaan dan sebagainya

c. Tes Berbicara Menggunakan Rangsang Visual

Tes ini dapat berbentuk pertanyaan mengenai waktu, jarak, dan ukuran sesuai gambar, membaca angka, mendeskripsikan gambar, menarasikan aktivitas atau gerakan, serta menarasikan cerita bergambar.

d. Tes melalui wawancara dan diskusi

Tes ini ditandai dengan persiapan berupa daftar pertanyaan yang tersetruktur yang harus dijawab oleh siswa. Teknik ini biasanya dilakukan pada mereka yang telah memiliki kemampuan bahasa Arab yang dirasa sudah cukup memadai sehingga memungkinkan untuk mengungkapkan pikiran dan perasaannya.

\section{B. TOAFL}

\section{Pengertian TOAFL}

TOAFL adalah singkatan dari "Test of Arabic as a Foreign Language”. Penamaan ini diilhami oleh TOEFL yang memang telah lebih dulu eksis. Pengambilan ini memang dimaksudkan agar TOAFL lebih mudah diucapkan dan lebih cepat dikenal oleh banyak orang, meskipun terkesan "mirip" TOEFL. Selain itu mengapa menggunakan TOAFL, adapun alasannya adalah sebagai berikut: ${ }^{16}$

a) Selama ini (UIN, IAIN, STAIN) belum mempunyai tes bahasa Arab standar seperti TOEFL.

b) Tes ini mampu mengukur tingkat kemampuan (reseptif) seseorang dalam berbahasa Arab.

c) Tes ini mudah dikerjakan dan mudah dikoreksi.

d) Jawaban dan hasil penilaiannya bersifat objektif dan pasti.

e) Materi tes ini cukup komprehensif, dan menurut pemahaman dan penguasaan mufradat yang cukup banyak.

\section{Tujuan TOAFL}

TOAFL merupakan standarisasi penilaian bahasa Arab. Diantara tujuan TOAFL adalah:

a) Menetapkan norma-norma keterampilan bahasa Arab yang kelak dijadikan sebagai pedoman standarisasi kelulusan bahasa Arab.

b) Memberlakukan standar baku kelulusan bahasa Arab dalam TOAFL.

${ }^{15}$ Moh. Matsna HS dan Erta Mahyudin, Pengembangan Evaluasi dan Tes Bahasa Arab, (Tangerang Selatan: Alkitabah, 2012), h. 153-156

${ }^{16}$ Muhbib Abdul Wahab, slide Presentasi Pembelajaran TOAFL di MAN 4 Jakarta tahun 2010 
c) Meningkatkan kualitas kemampuan dan penguasaan bahasa Arab bagi lulusan program S1, S2, dan S3 seluruh lembaga pendidikan di bawah naungan Kementerian Agama strata 1 sampai doktor. ${ }^{17}$

d) Menumbuhkan kesadaran peserta studi Islam dan ilmu pengetahuan akan signifikansi bahasa Arab sebagai media utama studi Islam dan ilmu pengetahuan.

e) Memberdayakan kemampuan memahami bahasa Arab.

f) Meningkatkan penguasaan kebahasaaraban berwacana studi Islam. ${ }^{18}$

\section{Sejarah Singkat TOAFL}

TOAFL "Test of Arabic as a Foreign Language" dibuat dan diterbitkan pertama kali pada tahun 1998 oleh sebuah Tim penyusun yang diprakarsai oleh Muhbib Abdul Wahab dan Suwito. Tim ini beranggotakan: ${ }^{19}$
a) Chotibul Umam
b) HD. Hidayat
c) Rofi'i
d) Akrom Malibary
e) Muhammad Matsna
f) Satria Effendi
g) Abdul Kadir Al-Habsyi

Tujuan awal pembentukan tim ini adalah untuk menyiapkan bahan tes standar bagi mahasiswa S1 dan S3 yang akan menyelesaikan studinya. Pada tahun 1999/2000, TOAFL "Test of Arabic as a Foreign Language". mulai digunakan sebagai salah satu materi tes, ujian masuk Program S2 dan S3 IAIN (kini UIN) Jakarta. Mulai 2005, Program S1 diwajibkan mengikuti TOAFL. Pada tahun 2000/2001. TOAFL juga digunakan sebagai materi tes masuk di beberapa Program Pascasarjana diluar UIN Jakarta, Seperti: ${ }^{20}$
a) PPs. IAIN Palembang
b) IAIN Lampung
c) STAIN Mataram
d) IAIN Padang
e) PPs. Studi Islam Universitas Muhammadiyah Jakarta
f) Diklat Diknas dan Deplu

\section{Visi dan Misi TOAFL}

Adapun visi dan misi TOAFL adalah sebagai berikut: ${ }^{21}$

Visi : Menjadikan bahasa Arab sebagai bahasa studi Islam dan ilmu pengetahuan

Misi :

a. Standarisasi dan sertifikasi tingkat kemampuan bahasa Arab peserta studi Islam dan ilmu pengetahuan di Indonesia, khususnya untuk program S1, S2, dan S3.

b. Mensosialisasikan model evaluasi kemampuan bahasa Arab yang memungkinkan penstudi Islam dan ilmu pengetahuan mengembangkan kemahirannya dalam bahasa Arab, terutama kemampuan memahami teks Arab.

${ }^{17}$ Muhammad Barmawi, Lulus TOAFL dengan Mudah dan Memuaskan, (Yogjakarta: DIVA Press, 2011), hlm. 11

${ }^{18}$ Muhbib Abdul Wahab, Op.cit.,

${ }^{19}$ Muhbib Abdul Wahab, Ibid.,

${ }^{20}$ Ibid.,

${ }^{21}$ Ibid., 


\section{Aspek-aspek Tes dan Jumlah Item Soal} berikut: ${ }^{22}$

Adapun aspek-aspek tes dan jumlah item soal TOAFL adalah sebagai

a. Fahm al-Masm $\hat{u}^{\prime}$, terdiri dari 50 item soal, meliputi:

1. Kemampuan memahami makna, pengertian, penalaran logis atau kesimpulan dari sebuah pernyataan/kalimat yang diperdengarkan. Jumlah soal untuk bagian ini sebanyak 20 item.

2. Kemampuan memahami maksud, topik, penalaran logis, kesimpulan dan makna tersirat dari dialog singkat antara dua orang. Jumlah soal untuk bagian ini sebanyak 15 item.

3. Kemampuan memahami maksud, topik, penalaran logis, kesimpulan dan makna tersirat dari dialog panjang antara dua orang atau lebih dan atau alenia pernyataan. Jumlah soal untuk bagian ini sebanyak 15 item.

4. Waktu yang dialokasikan \pm 30 -35 menit atau sampai bunyi kaset berakhir.

5. Soal-soal istima' hanya sekali dibacakan atau sama sekali tidak ada pengulangan.

b. Fahm al-Tarâkîb wa al- 'Ibârât, bagian ini terdiri dari 40 item soal, meliputi:

1. Kemampuan melengkapi kalimat dengan ungkapan atau struktur baku. Jumlah soal untuk bagian ini sebanyak 20 item.

2. Kemampuan memahami dan menganalisis penggunaan kata, ungkapan dan atau struktur yang salah dalam sebuah kalimat. Jumlah soal untuk bagian ini sebanyak 20 item.

3. Waktu yang dialokasikan hanya 30 menit.

c. Fahm al-Mufradât wa al-Nash al-Maktûb wa al-Qawâ'id, terdiri dari 60 item, meliputi:

1. Kemampuan memahami tarâduf (sinonim) atau kedekatan makna suatu yang digarisbawahi sesuai dengan konteks kalimat. Jumlah soal untuk bagian ini sebanyak 20 item.

2. Kemampuan memahami isi, topik dan makna tersirat dalam beberapa paragraf/wacana. Jumlah soal untuk bagian ini sebanyak 20 item.

3. Kemampuan memahami penggunaan, kedudukan (i'rab), derivasi, bentuk kata dan istilah-istilah nahwu dan sharaf. Jumlah soal untuk bagian ini sebanyak 20 item.

4. Waktu yang dialokasikan adalah 50 menit.

\section{Substansi Materi}

Adapun substansi materi TOAFL adalah sebagai berikut: ${ }^{23}$

e. Substansi soal-soal dalam TOAFL didasarkan pada buku-buku bahasa Arab standar, baik klasik maupun kontemporer.

f. Wacana yang diujikan meliputi pemikiran Islam (ilmu kalam/teologi, filsafat Islam, tasawuf), tafsir, ilmu tafsir, hadis, ilmu hadis, sejarah dan peradaban Islam, pemikiran politik Islam, pendidikan Islam, dakwah Islam, fiqh dan ushul fiqh, bahasa dan sastra Arab, ekonomi Islam, komunikasi, sosiologi, perkembangan modern/kontemporer dunia Islam dan perkembangan sains dalam berbagai bidang.

\section{Sistem Penilaian dan Skoring}

\footnotetext{
${ }^{22}$ Ibid.,

${ }^{23}$ Ibid.,
} 
Adapun penilaian dan scoring TOAFL adalah sebagai berikut:

a. Semua jawaban dicocokkan dengan kuncinya.

b. Jawaban salah tidak dikenakan penalti atau pengurangan.

c. Jumlah jawaban yang benar dikonversi dengan tabel skoring (yang diadaptasi dari sistem penilaian TOAFL).

d. Konversi ini menghasilkan skor mentah. Rumus konversi adalah nilai benar yang diperoleh ditambah 20 untuk bagian I, 30 untuk bagian II, dan 10 untuk bagian III.

e. Skor mentah ini kemudian diolah dengan rumus: Jumlah Skor Mentah x 10/3 $=$ Skor Akhir

\section{Standar Kelulusan TOAFL di STAIN Curup}

Pemberlakuan standar kelulusan TOAFL di STAIN Curup adalah 375 untuk jenjang S1 dan 425 untuk jenjang 425.

C. Hubungan Antara Kemampuan Muhadatsah Dengan Nilai TOAFL Pada Mahasiswa Prodi Pendidikan Bahasa Arab STAIN Curup

Untuk mengetahui hubungan antara kemampuan muhadatsah dengan nilai TOAFL mahasiswa prodi Pendidikan Bahasa Arab STAIN Curup, peneliti melakukan analisis antara nilai muhadatsah dengan nilai TOAFL. Peneliti mendapatkan nilai muhadatsah mahasiswa dari dosen yang mengajar muhadatsah. Adapun nilai muhadatsah mahasiswa Prodi Pendidikan Bahasa Arab adalah sebagai berikut:

Tabel II

Nilai Muhadatsah Mahasiswa PBA VIII A

\begin{tabular}{|c|c|c|}
\hline No & Nama & Nilai Muhadatsah (X) \\
\hline 1 & DWI MASRIANI & 80 \\
\hline 2 & EKA APRIANA & 65 \\
\hline 3 & RANI YUSPITA SARI & 80 \\
\hline 4 & MUKLIS SODIKIN & 90 \\
\hline 5 & FITRIA SANDORA & 79 \\
\hline 6 & FEBRI YANTI & 65 \\
\hline 7 & ARI JUNINDO & 70 \\
\hline 8 & MARDIYANTI & 80 \\
\hline 9 & NOPRIANDI & 84 \\
\hline 10 & ANA PAULA & 70 \\
\hline 11 & TITIK SOLEKAH & 80 \\
\hline 12 & $\begin{array}{l}\text { BAMBANG } \\
\text { HERIANTO }\end{array}$ & 81 \\
\hline
\end{tabular}




\begin{tabular}{|c|l|c|}
\hline 13 & SUHER WANTI & 90 \\
\hline 14 & MUKARRAM & 87 \\
\hline 15 & MASHURI & 80 \\
\hline 16 & RODIAH & 85 \\
\hline 17 & INDA YUSNITA & 80 \\
\hline 18 & SITI KHADIJAH & 90 \\
\hline 19 & ERI & 70 \\
\hline
\end{tabular}

Sedangkan nilai hasil TOAFL didapatkan dari pihak Unit Pengembangan Bahasa STAIN Curup selaku penyelenggara dari TOAFL. Adapun hasil TOAFL tersebut adalah sebagai berikut:

\section{Tabel II}

Nilai TOAFL Mahasiswa PBA VIII A

\begin{tabular}{|c|l|c|}
\hline No & \multicolumn{1}{|c|}{ Nama } & Hasil TOAFL (Y) \\
\hline 1 & DWI MASRIANI & 413 \\
\hline 2 & EKA APRIANA & 436 \\
\hline 3 & RANI YUSPITA SARI & 493 \\
\hline 4 & MUKLIS SODIKIN & 420 \\
\hline 5 & FITRIA SANDORA & 396 \\
\hline 6 & FEBRI YANTI & 380 \\
\hline 7 & ARI JUNINDO & 470 \\
\hline 8 & MARDIYANTI & 366 \\
\hline 9 & NOPRIANDI & 440 \\
\hline 10 & ANA PAULA & 393 \\
\hline 11 & TITIK SOLEKAH & 396 \\
\hline 12 & BAMBANG & 433 \\
\hline 13 & SERIANTO & 386 \\
\hline 14 & MUKARRAM & \\
\hline 15 & MASHURI & \\
\hline 16 & RODIAH & \\
\hline
\end{tabular}




\begin{tabular}{|c|l|c|}
\hline 17 & INDA YUSNITA & 436 \\
\hline 18 & SITI KHADIJAH & 500 \\
\hline 19 & ERI & 393 \\
\hline
\end{tabular}

Setelah mendapatkan nilai-nilai tersebut peneliti melakukan analisis terhadap data tersebut dengan menggunakan rumus Product Moment untuk melihat korelasi antara variable $\mathrm{x}$ yaitu kemampuan muhadatsah dengan variable y yaitu nilai TOAFL.

\section{Tabel III}

Tabel Analisis Hubungan Antara Nilai Muhadatsah Dengan Hasil TOAFL

\begin{tabular}{|c|l|c|c|c|c|c|}
\hline No & \multicolumn{1}{|c|}{ Nama } & $\mathrm{X}$ & $\mathrm{Y}$ & $\mathrm{X}^{2}$ & $\mathrm{Y}^{2}$ & $\mathrm{XY}$ \\
\hline 1 & DWI MASRIANI & 80 & 413 & 6400 & 170569 & 33040 \\
\hline 2 & EKA APRIANA & 65 & 430 & 4225 & 184900 & 27950 \\
\hline 3 & $\begin{array}{l}\text { RANI YUSPITA } \\
\text { SARI }\end{array}$ & 80 & 436 & 6400 & 190096 & 34880 \\
\hline 4 & $\begin{array}{l}\text { MUKLIS } \\
\text { SODIKIN }\end{array}$ & 90 & 493 & 8100 & 243049 & 44370 \\
\hline 5 & $\begin{array}{l}\text { FITRIA } \\
\text { SANDORA }\end{array}$ & 79 & 420 & 6241 & 176400 & 33180 \\
\hline 6 & FEBRI YANTI & 65 & 396 & 4225 & 156816 & 25740 \\
\hline 7 & ARI JUNINDO & 70 & 380 & 4900 & 144400 & 26600 \\
\hline 8 & MARDIYANTI & 80 & 470 & 6400 & 220900 & 37600 \\
\hline 9 & NOPRIANDI & 84 & 366 & 7056 & 133956 & 30744 \\
\hline 10 & ANA PAULA & 70 & 440 & 4900 & 193600 & 30800 \\
\hline 11 & $\begin{array}{l}\text { TITIK } \\
\text { SOLEKAH }\end{array}$ & 80 & 393 & 6400 & 154449 & 31440 \\
\hline 12 & $\begin{array}{l}\text { BAMBANG } \\
\text { HERIANTO }\end{array}$ & 81 & 396 & 6561 & 156816 & 32076 \\
\hline 13 & $\begin{array}{l}\text { SUHER } \\
\text { WANTI }\end{array}$ & 90 & 433 & 8100 & 187489 & 38970 \\
\hline 16 & MUUKARRAM & 87 & 386 & 7569 & 148996 & 33582 \\
\hline 17 & $\begin{array}{l}\text { INDA } \\
\text { YUSNITA }\end{array}$ & 80 & 433 & 6400 & 187489 & 34640 \\
\hline 18 & 486 & 7225 & 236196 & 41310 \\
\hline & & & 836 & 6400 & 190096 & 34880 \\
\hline
\end{tabular}




\begin{tabular}{|l|l|c|c|c|c|c|}
\hline & KHADIJAH & & & & & \\
\hline 19 & ERI & 70 & 393 & 4900 & 154449 & 27510 \\
\hline & Jumlah & 1506 & 8100 & 120502 & 3480666 & 644312 \\
\hline
\end{tabular}

$$
\begin{aligned}
\mathrm{r}_{11 / 22} & =\frac{\mathrm{N} \sum X Y-\left(\sum X\right)\left(\sum Y\right)}{\sqrt{\left[\mathrm{N} \sum X 2-\left(\sum X\right) 2\right]\left[\mathrm{N} \sum Y 2-\left(\sum Y\right) 2\right]}} \\
& =\frac{19 \times 644312-(1506)(8100)}{\sqrt{[19 \times 120502-(1506) 2][19 \times 3480666-81002]}} \\
& =\frac{12241928-12198600}{\sqrt{[2289538-2268036][66132654-65610000]}} \\
& =\frac{43328}{\sqrt{21502 \times 522654}} \\
& =\frac{43328}{\sqrt{11238106308}} \\
& =\frac{43328}{106009,93} \\
& =0,41
\end{aligned}
$$

Berdasarkan hasil analisis data dari rumus tersebut didapatkan koefisien korelasi antara kemampuan muhadatsah mahasiswa dengan nilai TOAFL adalah sebesar 0,41. Jadi, terdapat hubungan yang sedang antara kemampuan muhadatsah dengan nilai TOAFL. Hubungan tersebut hanya berlaku pada sampel 19 orang. Koefisien korelasi 0,41 menunjukkan bahwa $41 \%$ nilai TOAFL dipengaruhi oleh kemampuan muhadatsah dan 59\% disebabkan faktor-faktor lain.

Untuk mengetahui faktor-faktor lain yang ikut mempengaruhi nilai TOAFL dan supaya mendapatkan hasil penelitian yang akurat dan komprehensif, serta menguatkan apa yang telah didapatkan oleh peneliti, peneliti telah melakukan wawancara kepada responden. Wawancara ini ditekankan untuk mendapatkan informasi mengenai faktor-faktor lain yang menyebabkan nilai TOAFL tinggi ataupun rendah. Dari hasil wawancara, penulis menemukan beberapa faktor yang menentukan nilai TOAFL tersebut, yaitu sebagai berikut :

Pertama: Kondisi psikologis. Dalam mengikuti tes TOAFL, kondisi psikologis ikut menentukan keberhasilan dan kelulusan mahasiswa. Mahasiswa yang kondisi psikologis sedang tidak stabil dan sedang dirundung masalah akan membuat mereka tidak nyaman dan gelisah dalam menjawab setiap butir soal. Sedangkan tes harus dijawab dengan suasana hati yang tenang, agar setiap butir soal bisa dianalisa dengan baik sebelum menjawab.

Kedua: Kondisi fisik. Fisik yang sehat dan bugar ikut memberi andil pada keberhasilan tes TOAFL, dengan fisik yang sehat mahasiswa bisa berkonsentrasi penuh pada setiap pertanyaan yang diajukan dalam tes.

Ketiga: Strategi. Dengan menggunakan strategi jitu dalam menjawab soal TOAFL, maka kelulusan akan didapatkan. Walaupun tidak dapat menjawab semua dengan benar, tapi sudah cukup untuk mendapatkan skor yang diharapkan.

Keempat: Pengalaman. Mahasiswa yang telah pernah mengikuti tes TOAFL sebelumnya akan punya kesempatan lebih untuk lulus pada tes berikutnya, dikarenakan ia sudah punya gambaran mengenai soal-soal yang akan muncul dalm tes TOAFL tersebut.

Kelima: Keberuntungan. Tidak bisa dipungkiri faktor keberuntungan juga ikut menentukan kelulusan dalam tes TOAFL. Ada mahasiswa yang tidak ada persiapan dalam mengikuti tes, baik itu dari segi strategi, materi maupun strategi, tapi bisa lulus tes. 


\section{Simpulan}

Berdasarkan uraian diatas dapat disimpulkan sebagai berikut: Terdapat hubungan positif dengan kategori sedang antara kemampuan muhadatsah dengan nilai TOAFL mahasiswa Prodi Pendidikan Bahasa Arab STAIN Curup. Adapun faktor-faktor lain yang ikut mempengaruhi nilai TOAFL mahasiswa Prodi Pendidikan Bahasa Arab STAIN Curup adalah kondisi psikologis yang baik, fisik yang sehat, strategi jitu, pengalaman dan keberuntungan.

\section{E. Saran}

Sebagai mahasiswa prodi Pendidikan Bahasa Arab, mampu berbicara bahasa Arab dengan baik merupakan sebuah keharusan. Selain kemampuan berbicara bahasa Arab, nilai TOAFL juga menjadi ukuran kemahiran seseorang dalam bahasa Arab. Untuk itu diharapkan pada mahasiswa agar selalu berusaha untuk menerapkan bahasa Arab dalam berbicara sehari-hari dengan sesama mahasiswa prodi Pendidikan Bahasa Arab lainnya. Sedangkan dalam hal yang berkaitan dengan TOAFL hendaknya benar-benar menyiapkan diri secara fisik dan psikis serta selalu berlatih, mempelajari strategi jitu sebelum mengikuti tes tersebut.

\section{Daftar Pustaka}

Asrori, Imam dan Ahsanuddin, Moh. 2016. Media Pembelajaran Bahasa Arab Dari Kartu Sederhana Sampai Web Penjelajah Dunia, Malang: CV Bintang Sejahtera, 2016

Arikunto, Suharismi. 2010. Prosedur Penelitian, Jakarta: PT. Rineka Cipta

Barmawi, Muhammad. 2011. Lulus TOAFL dengan Mudah dan Memuaskan, Yogjakarta: DIVA Press

Djamarah, Syaiful Bahri dan Zain, Aswan. 2006. Strategi Belajar Mengajar, Jakarta: Rineka Cipta

Effendy, Ahmad Fuad. 2012. Metodologi Pengajaran Bahasa Arab, Malang: Misykat

Hermawan, Acep. 2009. Metodologi Pembelajaran Bahasa Arab, Bandung: PT Remaja Rosdakarya Offset

Izzan, Ahmad. 2007. Metodologi Pembelajaran Bahasa Arab, Bandung: Humaniora

Matsna, Moh dan Mahyudin, Erta. 2012. Pengembangan Evaluasi dan Tes Bahasa Arab.( Tangerang Selatan: Alkitabah

Ridwan, N.A. Kartu Kata dan Kartu Gambar sebagai media Pembelajaran Bahasa Arab di Madrasah Ibtidaiyah. Makalah disampaikan dalam Pelatihan Pembuatan dan Penggunaan Gambar dan Kartu Kata untuk Pembelajaran Bahasa Arab di Madrasah Ibtidaiyah, pada tanggal, 24-25 Juni 2006, Malang: Jurusan Sastra Universitas Negeri Malang

Rosyidi, Abdul Wahab. 2009. Media Pembelajaran Bahasa Arab, Malang: UIN Malang Press

Sugiyono. 2012. Metode Penelitian Pendidikan, Pendekatan Kuantitatif, Kualitatif, dan $R \& D$, Cetakan ke -17, Bandung: Alfabeta 
Tim Penyusun Kamus Pusat Bahasa. 2005. Kamus Besar Bahasa Indonesia, Edisi ketiga, Jakarta, Balai Pustaka

Wahab, Muhbib Abdul. 2010. slide Presentasi Pembelajaran TOAFL di MAN 4 Jakarta tahun

Wiraatmaja, Rochiati. 2005. Metode Penelitian Tindakan Kelas, Bandung: Remaja Rosdakarya

Yunus, Mahmud. 1990. Metode Khusus Bahasa Arab, Jakarta: PT. Hidakarya Agung 